\title{
Pemanfaatan Metode Recursive Largest First Dalam Penyusunan Shift Kerja Karyawan Pada Rumah Sakit Royal Prima Medan
}

\author{
Marlince NK Nababan ${ }^{1}$, Yonata Laia ${ }^{2}$ \\ 1,2 Program studi Sistem Informasi, Fakultas Teknologi dan Ilmu Komputer \\ Universitas Prima Indonesia Medan \\ ${ }^{1}$ marlince@ unprimdn.ac.id \\ 2*yonata@unprimdn.ac.id

\begin{tabular}{ccc}
\hline Diterima & Direvisi & Disetujui \\
$14-11-2019$ & $08-12-2019$ & $02-02-2020$ \\
\hline
\end{tabular}

\begin{abstract}
Abstrak - Penyusunan jadwal karywan merupakan salah satu komponen penting di setiap perusahaan yang memiliki karyawan yang dalam jumlah benyak. Dimana pada Rumah Sakit Umum Royal Prima memiliki jumlah karyawan 600 orang dengan itulah karyawan yang bersangkutan mengalami kendalah dalam penyusunan jadwal karyawan. Berdasarkan data yang di dapatkan dari karyawan yang bersangkutan mengatakan penyususan penjadwalan karwayan dengan jaumlah 600 orang membutuhkan waktu 1 miggu. Pada penelitian menggunakan metode RLF dalam penysusunan penjadwawaln karyawan. Berdasarkan hasil yang di dapatkan dengan metode yang digunakan adalah pengerjaan penyusunan penjadwalan karyawan denga metode RLF lebih baik dari pada pekerjaan sebelumnya. Dimana pada metode yang sebelumnya harus menunggu waktu seminggu dalam pengerjaan penyusuanan penejadwalan karywan, dengan aplikasi memekau metode RLF ini dapat terselesaikan dalam 1 hari.
\end{abstract}

Kata Kunci: Penjadwalan, RLF, Karyawan

Abstract - Employee scheduling is an important component in every company that has a number of employees. Where in the Royal Prima General Hospital has a number of employees of 600 people that is the employee concerned experienced constraints in preparing employee schedules. Based on the data obtained from the employee concerned, it is said that compiling 600 employees for scheduling jobs takes 1 week. In the study using the RLF method in preparing employee scheduling. Based on the results obtained by the method used is the preparation of employee scheduling with the RLF method better than the previous job. Where the previous method had to wait a week in the process of preparing employee scheduling, with the application of capturing this RLF method can be completed in 1 day.

Keywords: Scheduling, RLF, Employees

\section{PENDAHULUAN}

Hal ini dikarenakan adanya bantuan alat yang berteknologi canggih yang dapat mengolah data menjadi informasi yang dibutuhkan, seperti komputer. Hal ini menyebabkan organisasi maupun perusahaan dimasa sekarang ini mulai mengelola data dan informasi mereka dengan menggunakan komputer. Dengan adanya penggunaan komputer maka kegiatan operasional perusahaan dapat dilaksanakan dengan prinsip tepat waktu, tepat guna, tepat sasaran dan dapat dipertanggung-jawabkan.

Penjadwalan merupakan salah satu proses penting dalam kehidupan manusia. Penjadwalan merupakan kegiatan yang harus dimiliki oleh setiap orang untuk dapat membantu dalam melakukan aktivitasnya sehari-hari. Terlebih lagi sebuah instansi atau lembaga yang memiliki agendaagenda penting yang harus diselesaikan secara teratur dan rapi. Begitu pentingnya penjadwalan ini agar kegiatan dapat berjalan sesuai dengan yang telah direncanakan (Rifai, 2011). penjadwalan merupakan satu masalah paling sering yang dihadapi di berbagai bidang kehidupan sehari-hari seperti penjadwalan di kampus, jadwal ujian, jadwal penerbangan, pekerjaan dan masalah pengaturan jadwal kereta api.Masalah-masalah ini dapat di selesaikan menggunakan berbagai metode dengan menggunakan meta-heuristik dan algoritma, (Menurut Nader Chmait dan Khalil Challita, 2013). Peneliti terdahulu algoritma RLF digunakan membantu pengambilan keputusan dalam penjadwalan dengan menghasilkan pewarnaan graf dengan pewarnaan simpul yang sama, (Sadar 2014). Algoritma RLF digunakan untuk menyelesaikan masalah pengaturan waktu dalam skala yang besar. Metode ini dengan konsep mewarnai grafik dengan waktu yang ditentukan. Langkah-langkah algoritma 
RLF menggunkaan heuristik untuk mengidentifikasi rangkaian simpul independen dalam bentuk grafik sampai menghasilkan subgraph minimum. Grafik dapat memodelkan masalah dalam jumlah yang besar termasuk jejaring sosial, penjadwalan, pengiriman paket, teknik elektro dan jaringan komputer. Masalah-masalah dalam pewarnaan grafik yaitu menentukan warna untuk semua simpul dengan warna yang berbeda dan jumlah yang berbeda, (R.M.R. Lewis 2014).

pewarnaan graf memecahkan berbagai masalah yaitu mewarnai peta, mengatur jadwal dan penjadwalan. Pewarnaan graf diasosiasikan dengan dua jenis pewarnaan sebagai pewarnaan vertex dan edge. Tujuan dari kedua jenis pewarnaan adalah untuk mewarnai seluruh grafik tanpa kesalahaan, (Menurut Murat dan Nurdan Akhan Baykan 2016). penjadwalan adalah pengalokasian sumber daya dari waktu ke waktu untuk menunjang pelaksanaan dan penyelesaian suatu aktivitas pengerjaan spesifik. Penentuan alokasi sumber daya perusahaan (sumber daya manusia, sumber daya kapasitas dan peralatan produksi atau mesin-mesin, dan waktu) ditunjukkan untuk mewujudkan sasaran penggunaan sumber daya secara efektif dan efisien, sekaligus menghasilkan keluaran (output) yang tepat jumlah, tepat waktu, dan tepat kualitas K. R. Baker and D. Trietsch (2013), M. Firdaus, I. Masudin, and D. M. Utama (2015)

Rumah sakit royal prima adalah salaha satu perusahaan bergerak dibidang kesahatan. Saat ini, perusahaan masih menerapkan sistem manual dalam melakukan pengaturan jadwal shift kerja karyawan sehingga proses penjadwalan secara manual ini sering mengalami masalah seperti keterlambatan untuk penentuan tanggung jawab masing-masing karyawan. Oleh karena itu, maka diperlukan sebuah sistem penjadwalan yang terkomputerisasi. Salah satu algoritma yang dapat digunakan untuk melakukan pengambilan keputusan dan penjadwalan dimana dengan pewarnaan simpul graph adalah algoritma Recursive Largest First.

Berdasarkan uraian di atas, penulis ingin merancang suatu perangkat lunak yang mampu untuk melakukan proses penjadwalan dengan menggunakan algoritma RLF. Oleh karena itu, penulis mengambil penelitian dengan judul "Aplikasi Penjadwalan Shift Kerja Karyawan dengan Algoritma Recursive Largest First (RLF) pada Rumah sakit royal prima medan”.

\section{A. Penjadwalan}

Menurut Rinaldi Munir, (2014). Penjadwalan merupakan kumpulan kebijaksanaan dan mekanisme yang berkaitan dengan urutan kerja yang harus dilakukan. Penjadwalan bertugas untuk memutuskan:

1. Proses yang harus berjalan.

2. Kapan dan selama berapa lama proses itu berjalan.
Persoalan menentukan jadwal waktu kerja dapat dideskripsikan sebagai berikut, misalkan terdapat delapan orang karyawan $(1,2, \ldots, 8)$ dan jadwal waktu kerja yang dapat dipilihnya (A, B, C, D, E). Tabel berikut memperlihatkan matriks jadwal waktu kerja dan delapan orang karyawan. Angka 1 pada elemen (i, j) berarti karyawan i memilih jadwal waktu kerja $\mathrm{j}$, sedangkan angka 0 menyatakan karyawan i tidak memilih jadwal waktu kerja.

Tabel 1. Daftar yang Diambil oleh Karyawan

\begin{tabular}{|l|l|l|l|l|l|}
\hline & A & B & C & D & E \\
\hline 1 & 0 & 1 & 0 & 0 & 1 \\
\hline 2 & 0 & 1 & 0 & 1 & 0 \\
\hline 3 & 0 & 0 & 1 & 1 & 0 \\
\hline 4 & 1 & 1 & 0 & 0 & 0 \\
\hline 5 & 0 & 1 & 0 & 1 & 0 \\
\hline 6 & 0 & 0 & 1 & 1 & 0 \\
\hline 7 & 1 & 0 & 1 & 0 & 0 \\
\hline 8 & 0 & 0 & 1 & 1 & 0 \\
\hline
\end{tabular}

(Sumber : Rinaldi Munir, 2014)

Berdasarkan tabel di atas, administratur jadwal waktu kerja ingin menentukan jadwal masuk kerja sedemikian sehingga semua karyawan dapat masuk kerja yang diambilnya tanpa bertabrakan waktunya dengan jadwal waktu kerja lain yang juga diambilnya. Solusi dari contoh permasalahan di atas dapat dilihat pada gambar berikut:
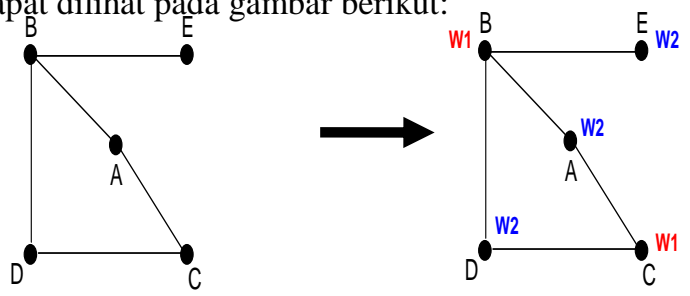

Gambar 1. Solusi dari Permasalahan pada Tabel 2.1 (Sumber : Rinaldi Munir, 2014)

B. Algoritma Pewarnaan Simpul Graph Recursive Largest First

Algoritma Recursive Largest First yang merupakan varian dari algoritma Welch-Powell ini ditemukan oleh Leighton. Algoritma ini merupakan salah satu algoritma yang paling sering digunakan untuk mewarnai sebuah graph G. (Rinaldi Munir, 2014).

\section{Graph}

Teori graph merupakan pokok bahasan yang sudah tua usianya namun memiliki banyak terapan sampai saat ini. Graph digunakan untuk merepresentasikan objek-objek diskrit dan hubungan antara objek-objek tersebut. Dengan diberikannya peta tersebut, maka dapat diketahui apakah ada lintasan jalan antara dua buah kota. Selain itu, bila panjang jalan kereta api antara dua buah kota bertetangga diketahui, maka juga dapat ditentukan rute perjalanan tersingkat dari kota A ke kota B. (Rinaldi Munir, 2014).

D. Definisi Graph

Secara matematis, graph $\mathrm{G}$ dapat didefinisikan sebagai pasangan himpunan $(\mathrm{V}, \mathrm{E})$, ditulis dengan 
notasi $\mathrm{G}=(\mathrm{V}, \mathrm{E})$, yang dalam hal ini $\mathrm{V}$ adalah himpunan tidak kosong dari simpul-simpul (vertices atau nodes) dan $\mathrm{E}$ adalah himpunan sisi (edges atau arcs) yang menghubungkan sepasang simpul.

Definisi diatas menyatakan bahwa $\mathrm{V}$ tidak boleh kosong, sedangkan E boleh kosong. Jadi, sebuah graph dimungkinkan tidak mempunyai sisi satu buah pun, tetapi simpulnya harus ada, minimal satu. Graph yang hanya mempunyai satu buah simpul tanpa sebuah sisi pun dinamakan graph trivial.

Simpul pada graph dapat dinomori dengan huruf, seperti a, b, c, ... atau dengan bilangan asli 1, 2, 3, ... ataupun dengan gabungan keduanya. Sedangkan sisi yang menghubungkan simpul u dengan simpul v dinyatakan dengan pasangan $(\mathrm{u}, \mathrm{v})$ atau dinyatakan dengan lambang e1, e2, .... Dengan kata lain, jika e adalah sisi yang menghubungkan simpul u dengan simpul v, maka e dapat ditulis:

$\mathrm{e}=(\mathrm{u}, \mathrm{v})$

Secara geometri graph digambarkan sebagai sekumpulan noktah (simpul) di dalam bidang dua dimensi yang dihubungkan dengan sekumpulan garis (sisi). Berikut diberikan beberapa contoh graph :

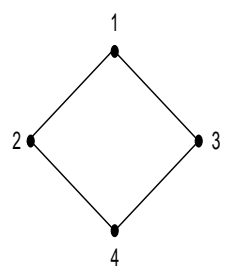

(a) $G_{1}$

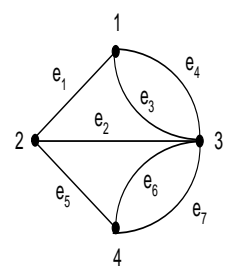

(b) $G_{2}$

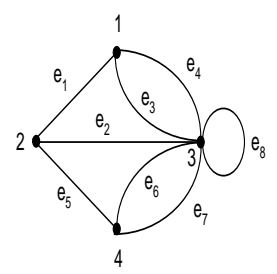

(c) $G_{3}$
(Sumber : Rinaldi Munir, 2014)

Gambar 2. Tiga buah graph (a) graph sederhana, (b) graph ganda, dan (c) graph semu

G2 adalah graph dengan himpunan simpul V dan himpunan sisi E yaitu :

$\mathrm{V}=\{1,2,3,4\}$

$\mathrm{E}=\{(1,2),(2,3),(1,3),(1,3),(2,4),(3,4),(3,4)\}$

$\square$ himpunan ganda

$=\{\mathrm{e} 1, \mathrm{e} 2, \mathrm{e} 3, \mathrm{e} 4, \mathrm{e} 5, \mathrm{e} 6, \mathrm{e} 7\}$

G3 adalah graph dengan himpunan simpul V dan himpunan sisi E yaitu :

$\mathrm{V}=\{1,2,3,4\}$

$\mathrm{E}=\{(1,2),(2,3),(1,3),(1,3),(2,4),(3,4),(3,4)$, $(3,3)\}$

$\square$ himpunan ganda

$=\{\mathrm{e} 1, \mathrm{e} 2, \mathrm{e} 3, \mathrm{e} 4, \mathrm{e} 5, \mathrm{e} 6, \mathrm{e} 7, \mathrm{e} 8\}$

Pada G2, sisi e $3=\{1,3\}$ dan sisi e $4=\{1,3\}$

dinamakan sisi ganda (multiple edges atau paralel edges) karena kedua sisi ini menghubungi dua buah simpul yang sama, yaitu simpul 1 dan simpul 3 . Pada G3, sisi e8 = $(3,3)$ dinamakan gelang atau kalang (loop) karena berawal dan berakhir pada simpul yang sama. (Rinaldi Munir, 2014).

penjadwalan adalah pengalokasian sumber daya dari waktu ke waktu untuk menunjang pelaksanaan dan penyelesaian suatu aktivitas pengerjaan spesifik. Penentuan alokasi sumber daya perusahaan (sumber daya manusia, sumber daya kapasitas dan peralatan produksi atau mesin-mesin, dan waktu) ditunjukkan untuk mewujudkan sasaran penggunaan sumber daya secara efektif dan efisien, sekaligus menghasilkan keluaran (output) yang tepat jumlah, tepat waktu, dan tepat kualitas K. R. Baker and D. Trietsch (2013), M. Firdaus, I. Masudin, and D. M. Utama (2015).

\section{METODOLOGI PENELITIAN}

\section{A. Analisa}

Perangkat lunak pengambilan keputusan dalam penjadwalan dengan algoritma RLF ini membahas mengenai penerapan algoritma pewarnaan simpul graph tersebut dalam melakukan penjadwalan. Algoritma RLF ini mewarnai simpul graph dengan berdasarkan pada jumlah simpul tetangga yang belum diwarnai dari simpul graph tersebut. Simpul graph yang memiliki jumlah simpul tetangga yang belum diwarnai yang paling banyak akan diproses terlebih dahulu. Kemudian, semua simpul graph yang tidak bertetangga dengan simpul tersebut dan tidak saling bertetangga akan diwarnai dengan warna yang sama dengan simpul tersebut. Proses tersebut akan diulang hingga semua simpul graph selesai diwarnai.

B. Instrumen Perangkat Lunak dan Perangkat Keras Dalam perancangan aplikasi ini ada beberapa Software dan hardware yang akan disipakan. Adapun perangkat lunak (software) yang digunakan dalam penelitian ini berupa Aplikasi Visual Studio 2010 dan database Microsoft access 2010. Sedangkan spesifikasi dari perangkat keras (hardware) berupa 1 unit otebook/laptop.

\section{Perancangan Pengujian}

Pengujian ini dilakukan dengan pengujian blackbox, yaitu sebuah metode yang digunakan untuk menemukan kesalahan dan mendemonstrasikan fungsional aplikasi saat dioperasikan, apakah input diterima dengan benar dan output yang dihasilkan telah sesuai dengan yang diharapkan, sehingga dapat membuktikan kebenarannya.

\section{HASIL DAN PEMBAHASAN}

\section{A. Diagram Blok proses RLF}

Digaram blok secara umum penelitian ini dapat dilihat pada diagram blok dibawah ini :

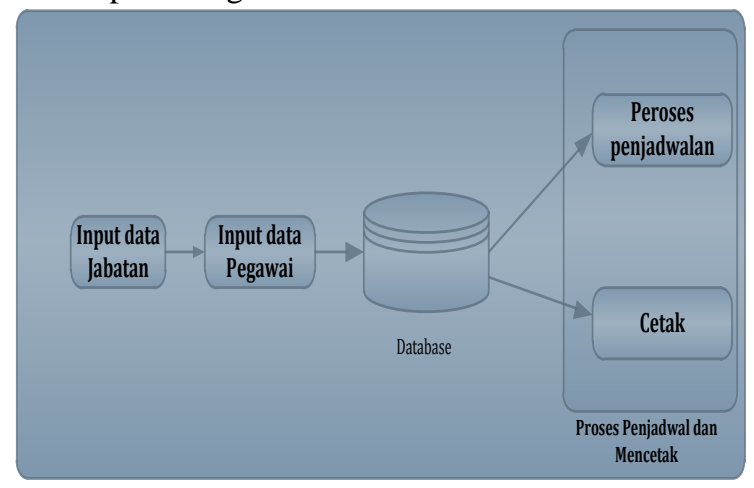




\section{Gambar 3. Diagram Blok proses RLF}

B. Metode Perancangan Sistem

Untuk mengetahui rincian langkah kerja dari algoritma RLF maka dapat dilihat pada deskripsi flowchart seperti terlihat pada gambar berikut:

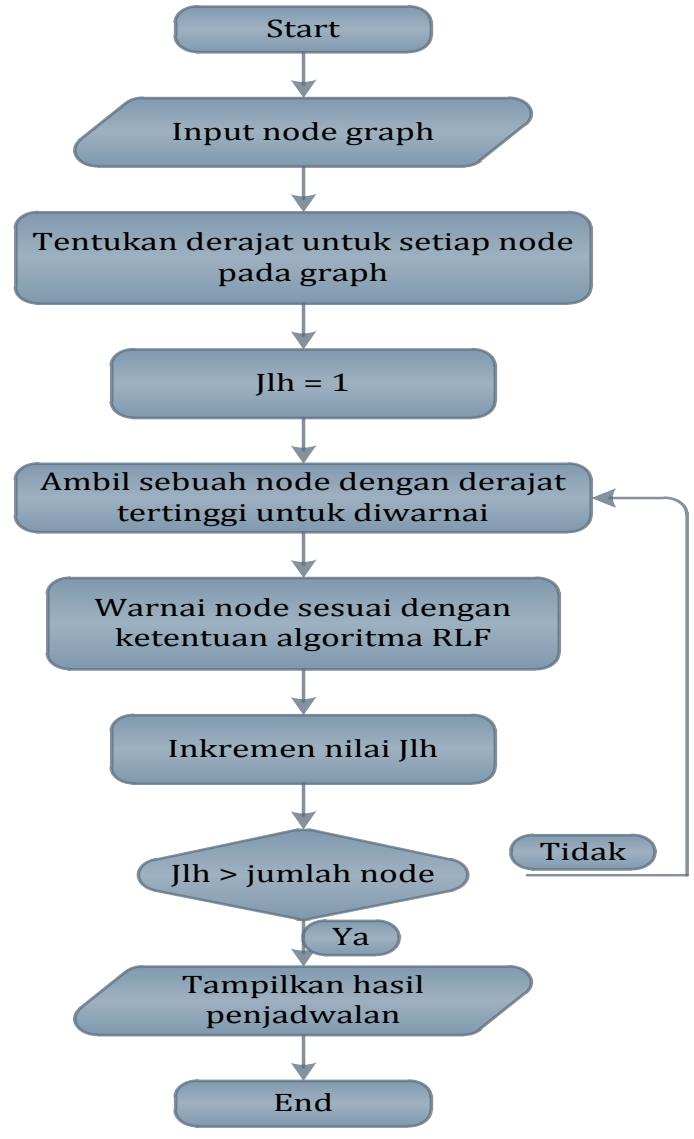

Gambar 4. Rancangan Flowchart Diagram

Seperti terlihat pada gambar 4 , proses penjadwalan akan dimulai dari penentuan node dari graph yang merupakan representasi dari staf pada perusahaan. Setelah itu, proses akan dilanjutkan dengan pemilihan node yang akan diwarnai dengan dimulai dari node dengan derajat terbesar. Proses pewarnaan node graph akan diulangi hingga semua node diwarnai. Warna node yang sama berarti dua staf tersebut boleh dijadwalkan dalam ruangan yang sama.

\section{Perancangan}

Perangkat lunak pengambilan keputusan dalam penjadwalan dengan algoritma Recursive Largest First ini dirancang dengan menggunakan bahasa pemrograman Microsoft Visual Basic.NET dengan menggunakan beberapa objek dasar seperti :

1) Label, yang digunakan untuk menampilkan keterangan.

2) Shape, yang digunakan sebagai dekorasi tambahan.

3) MSFlexgrid, yang digunakan untuk menampilkan data-data simpul graph dan juga sebagai tempat penginputan data variabel dan daftar nama variabel.
4) Command button, yang digunakan sebagai tombol eksekusi.

5) Combo Box, yang digunakan untuk menyediakan pilihan dan juga sebagai tempat penginputan data.

6) Text Box, yang digunakan untuk menampilkan data variabel terikat.

7) Image, yang digunakan untuk memunculkan gambar simpul graph.

8) Picture Box, yang digunakan sebagai tempat penggambaran graph.

D. Rencana Kerja

Rencana kerja sistem Analisa dan Implementasi Recursive Largest First (RLF) :

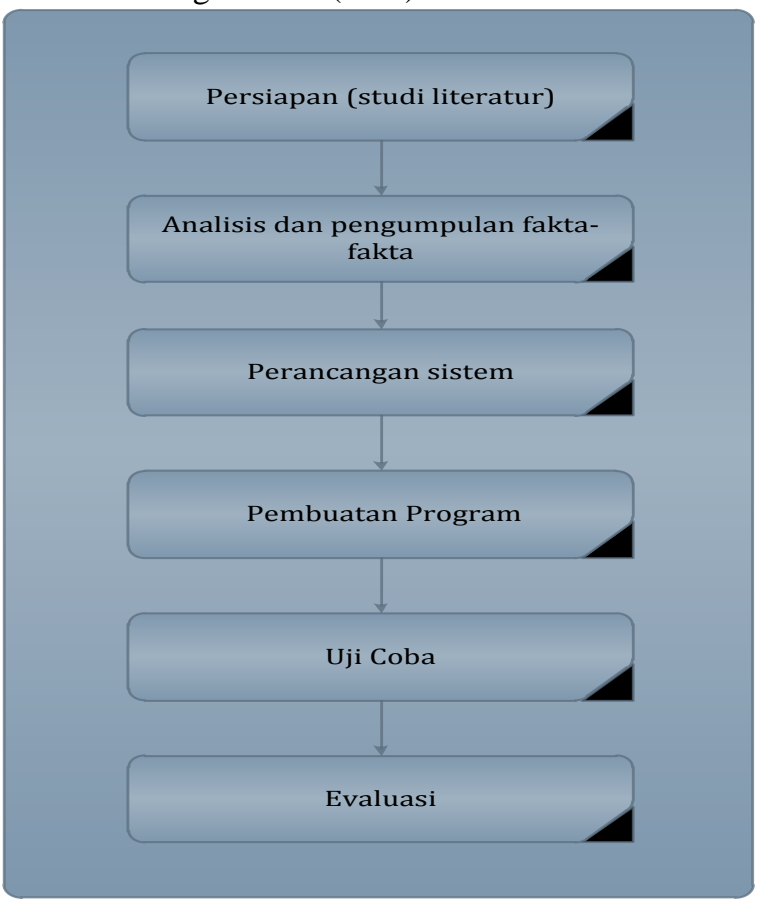

Gambar 5. Rencana Kerja

\section{KESIMPULAN}

Berdasarkan hasil yang di dapatkan dengan metode yang digunakan adalah pengerjaan penyusunan penjadwalan karyawan denga metode RLF lebih baik dari pada pekerjaan sebelumnya. Dimana pada metode yang sebelumnya harus menunggu waktu seminggu dalam pengerjaan penyusuanan penejadwalan karywan, dengan aplikasi memakai metode RLF ini dapat terselesaikan dalam 1 hari.

\section{REFERENSI}

Ulisna Ade Rifai, 2011 "Pengembangan sistem informasi penjadwalan kegiatan dengan menggunakan algoritma genetika”, Jakarta.

Nader Chmait, Khalil Challita,2013" Using Simulated Annealing and Ant-Colony Optimization Algorithms to Solve the 
Scheduling Problem", Computer Science and Information Technology 1(3): 208-224, 2013.

Sadar Aman Gulo, 2014 "Perangkat Lunak Pengambilan Keputusan Dalam Penjadwalan Dengan Metode Recursive Largest First", Pelita Informatika Budi Darma, Volume : ViI, Nomor: 3 .

R.M.R. Lewis, "A Guide to Graph Colouring Algorithms and Applications", Springer, 4245

Murat Aslan, Nurdan Akhan Baykan,2016"A Performance Comparison of Graph Coloring Algorithm, International Conference on Advanced Technology \& Sciences (ICAT'16).

Jenal, R, Ismail, WR, Yuen LC, Oughalime, A. 2011. A Cyclical Nurse Schedule Using Goal
Programming. Universiti Kebangsaan Malaysia, Selangor, Malaysia.

Rinaldi Munir, Struktur Diskrit, 2008, Departemen Teknik Informatika, Institut Teknologi Bandung.

K. R. Baker and D. Trietsch, Principles of sequencing and scheduling: John Wiley \& Sons, 2013.

L. M. Firdaus, I. Masudin, and D. M. Utama, "Penjadwalan Flowshop Dengan Menggunakan Simulated Annealing," Spektrum Industri, vol. 13, 2015. 